\title{
Numerical Simulation of Fire Smoke Spread in a Super High-Rise Building for Different Fire Scenarios
}

\author{
Xin Yi, ${ }^{1,2}$ Changkui Lei $\left(D,{ }^{1}\right.$ Jun Deng, ${ }^{1,2}$ Li Ma, ${ }^{1,2}$ Jing Fan, ${ }^{1}$ Yuanyuan Liu, ${ }^{1}$ Lei Bai, ${ }^{1,2}$ \\ and Chi-Min Shu ${ }^{3}$ \\ ${ }^{1}$ School of Safety Science and Engineering, Xi'an University of Science and Technology, Xi'an, China \\ ${ }^{2}$ Shaanxi Key Laboratory of Prevention and Control of Coal Fire, Xi'an, China \\ ${ }^{3}$ Graduate School of Engineering Science and Technology, National Yunlin University of Science and Technology, 123, \\ University Rd., Sec. 3, Douliou, Yunlin, Taiwan \\ Correspondence should be addressed to Changkui Lei; lchangkui@126.com
}

Received 16 February 2019; Revised 16 April 2019; Accepted 28 April 2019; Published 14 May 2019

Academic Editor: Behzad Esmaeili

Copyright (C) 2019 Xin Yi et al. This is an open access article distributed under the Creative Commons Attribution License, which permits unrestricted use, distribution, and reproduction in any medium, provided the original work is properly cited.

\begin{abstract}
Research on fire spread in super high-rise buildings is crucial for identifying feasible methods of fire prevention and personnel evacuation. In this study, a fire spread model was established based on the fire dynamics simulator (FDS), and fire spread results were analyzed for a fire scenario in a single room under different conditions, a fire scenario in different functional places under the same conditions, and the spread of fire outside of the room. The results revealed that the critical time required for a fire to become a safety hazard in a shop, a restaurant, or an office was approximately $200 \mathrm{~s}$. The same type of fire reached the critical time required for a fire to become a safety hazard more quickly in an office than a restaurant or shop, regardless of whether the fire spread was caused by CO mass fraction or temperature. More attention should be paid to fire safety in office spaces in super high-rise buildings. Furthermore, compared with CO mass fraction and temperature, visibility was a more influential factor in determining the critical time required for fire to become a hazard, and smoke affected the adjacent open area in approximately $60 \mathrm{~s}$. In the event of a fire, the temperature of the staircase and its front chamber was always lower than the threshold temperature of $60^{\circ} \mathrm{C}$ for human body tolerance.
\end{abstract}

\section{Introduction}

With the rapid development of modern urban processes and the progress of architectural science and technology, numerous super high-rise buildings continue to be constructed [1-4]. Some super high-rise buildings have become prominent symbols of city modernization and urbanization, particularly those in metropolitan areas, such as the Burj Khalifa in Dubai, Shanghai Tower, and Goldin Finance 117 in Tianjin. Super high-rise buildings bring people enjoyment and optimize the land area used. However, the height and number of these buildings increases, so do the number and variety of internal combustibles. Problems associated with super high-rise buildings, such as vertical traffic problems, structural problems, and security concerns, have also become increasingly prominent [5-9].

Compared with general building fires, super high-rise building fires have unique characteristics [10]: (1) fire spreads quickly, (2) super high-rise buildings have numerous fire hazards, (3) complex building structures and boundary environments cause particular fire evolution behaviors, (4) crowd evacuation in super high-rise buildings is a major safety concern, (5) fire rescue is difficult and the amount of time required to fight a fire is long, allowing the fire to readily spread, and (6) fires cause substantial loss and grave social consequences. Therefore, identifying methods for effectively preventing the occurrence, development, and spread of fire in super high-rise buildings, ensuring safe evacuation of internal personnel, and reducing casualties and property damage have become crucial concerns in the field of firefighting [11-15]. In the current research on highrise building fires, NFPA92B is the most widely recognized and used. At the same time, researchers generally conduct research through theoretical analysis, numerical simulation, and CFD simulation methods, mainly to study the spread of smoke and evacuation of people in high-rise building fire. 
Zhu et al. [16] conducted research on smoke control in super high-rise building fires. Based on the CCTV North Building fire, Hou et al. [17] numerically simulated the fire spread and temperature distribution of high-rise buildings. Liu et al. [18] analyzed in detail the fire causes of high-rise building fires and proposed protective measures to facilitate evacuation. Yang et al. [19] also simulated the variation of smoke and temperature fields in a high-rise residential building in Japan by numerical simulation. Xia [20] simulated the spread of fire smoke in an elevator shaft of a high-rise building, and Cheng and Hadjisophocleous [21] produced a dynamic model of fire spread that investigated the spread of fire in both horizontal and vertical directions. Jiang et al. [22] published an independent review of the performance of Shanghai Tower in the event of a fire. Sun et al. [23] reviewed the contemporary research on the dynamics of fires in highrise buildings. Zhang and Ren [24] used a super high-rise building in Chongqing as an example, adopting FDS and the simulation of transient evacuation and pedestrian movements to simulate the spread of smoke and evacuation in a general fire scenario and offered several suggestions for fire safety. Chen et al. [25] proposed an event-driven agent-based modeling approach to quantitatively evaluate elevator-assisted evacuation processes. Yu-ting and Zhou [26] discussed the fire safety status of the building after the 2015 fire accident in Dubai and mentioned the importance of fire protection standards and firefighting equipment. Xu et al. [27] conducted a hot smoke test in the $60 \mathrm{~m}$ high atrium of the Shanghai Tower and studied in detail the movement laws and smoke characteristics of fire smoke.

For example, firefighting, smoke control, and personnel evacuation in super high-rise buildings are still beset by certain technical challenges [28-31]. Therefore, using scientific approaches to simulate fire scenarios to understand common modes and characteristics of fire spread is valuable for fire prevention and disaster reduction in super high-rise buildings [32, 33].

This study selected an actual super high-rise building to set up specific fire scenarios, establish a FDS fire model, and analyze the direction and type of spread for a fire in different fire scenarios.

\section{Fire Scenario Settings of the Super High-Rise Building}

2.1. Building Overview. Basically, the combustion characteristics of high-rise and super high-rise fires are the same; with that the potential spreads many ways, the speed is fast, the fire control is difficult, and the chimney effect is easy to form. The reliability of super high-rise fire facilities is low, the external rescue is difficult, and the environmental conditions are greatly affected. In the existing simulations, the influence of environmental factors on the combustion process of super high-rise buildings is less considered. For example, the boundary conditions such as air velocity and grid setting do not fully consider the characteristics of actual buildings, and there are few fire researches on super high-rise buildings. The research object of this study was the Saigao office, located in Shaanxi Province, China. The building has an approximate height of $150 \mathrm{~m}$, with a total floor area of $85,532 \mathrm{~m}^{2}$, a building area of $78,836 \mathrm{~m}^{2}$ for 35 stories above ground level, and a building area of $6,696 \mathrm{~m}^{2}$ for 3 stories located underground. The building consists of a steel-reinforced concrete frame reinforcing a concrete coretube structure. The building functions are listed in Table 1.

2.2. Parameter Setting for Fire Scenarios. In the fire settings, the factors determining the degree and speed of fire development were mainly the heat release of the combustion material, fire growth factors, and the ambient temperature affecting the height of the neutral surface of the building. Moreover, this study combined the places for critical fire prevention to establish the fire parameters.

2.3. Heat Release. According to Shanghai's "Technical specification for building smoke control DGJ 08-88-2006", the thermal temperature released in each place varies depending on whether a sprinkler system is set up or not, as indicated in Table 2.

2.4. Fire Growth Factors. Rate of fire growth is a crucial indicator for measuring the risk of fire and is related to the storage of combustibles, combustion characteristics, spatial characteristics, the presence of water sprinkler systems, and ventilation devices. The relationship between fire heat release rate and duration can be expressed by

$$
Q_{\mathrm{f}}=\alpha\left(t-t_{0}\right)^{2}
$$

where $Q_{\mathrm{f}}$ is the fire heat release rate in $\mathrm{kW}, \alpha$ is the fire growth factor in $\mathrm{kW} / \mathrm{s}^{2}, t$ is the fire burning time in $s$, and $t_{0}$ is the smoldering time of the fire in $s$.

Because of the small effect of smoldering on the spread of fire, smoldering time $t_{0}$ is usually ignored. Accordingly, equation (1) can be simplified as follows:

$$
Q_{\mathrm{f}}=\alpha t^{2} \text {. }
$$

Fire growth factors for different fire types are provided in Table 3. The primary functions of the super high-rise building used in this study are business and office-related activities, which feature a dense distribution of internal combustible material. Therefore, the typical fire type in such a building can be defined as a fast fire type with a fire growth factor $\alpha$ of 0.04689 .

2.5. Ambient Temperature. In China, the State Council has promoted a campaign that restricts the temperature of air conditioning in public buildings, with the exception of those in certain industries; the temperature can be neither lower than $26^{\circ} \mathrm{C}$ in the summer nor higher than $20^{\circ} \mathrm{C}$ in the winter. Thus, the ambient temperature used in this study was set at $23^{\circ} \mathrm{C}$.

2.6. Fire Scenario Setting. According to the distribution of the building functional area and the process of smoke spread in different spaces, six fire places were deliberately selected and set up for simulation studies, as detailed in Table 4. 
TABLE 1: Summary of the super high-rise building functions.

\begin{tabular}{lc}
\hline Floor & Function \\
\hline Underground 2nd and & Garage and equipment rooms \\
3rd floors & Equipment and commercial space \\
Underground 1st floor & Office hall and commercial space \\
1st floor & Commercial space \\
2nd to 6th floors & Refuge story \\
7th and 21st floors & Low office \\
8th to 20th floors & High office \\
22nd to 35th floors & \\
\hline
\end{tabular}

TABLE 2: Heat release for various sprinkler systems.

\begin{tabular}{lc}
\hline Places & Heat release Q (MW) \\
\hline Mall with a sprinkler system & 5.0 \\
Office and room with a sprinkler system & 1.5 \\
Public place with a sprinkler system & 2.5 \\
Office and room without a sprinkler system & 6.0 \\
Public place without a sprinkler system & 8.0
\end{tabular}

TABLE 3: Fire growth factors for various fires.

\begin{tabular}{lcc}
\hline Fire type & $\begin{array}{c}\text { Typical combustible } \\
\text { material }\end{array}$ & $\begin{array}{c}\text { Fire growth } \\
\text { factor }\left(\mathrm{kW} / \mathrm{s}^{2}\right)\end{array}$ \\
\hline $\begin{array}{l}\text { Slow-spreading fire } \\
\text { Medium-spreading } \\
\text { fire }\end{array}$ & $\begin{array}{c}\text { Hardwood furniture } \\
\text { Cotton and polyester mats }\end{array}$ & 0.00293 \\
$\begin{array}{l}\text { Fast-spreading fire } \\
\text { Ultra-fast-spreading } \\
\text { fire }\end{array}$ & $\begin{array}{c}\text { Wooden shelves and foam } \\
\text { Pool fire, fast-burning } \\
\text { decorative furniture, } \\
\text { and light curtains }\end{array}$ & 0.01172 \\
\hline
\end{tabular}

2.7. Fire Hazard Criteria. Considering that the study of fire hazard is usually to ensure the safe evacuation of personnel, it is usually taken in conjunction with the environmental limit which the human body can withstand [34, 35]. Generally, it is considered from three aspects: the smoke layer height, the clear layer temperature, and the visibility, from a position $2.0 \mathrm{~m}$ above the ground.

(1) In this paper, the respirable air temperature not higher than $60^{\circ} \mathrm{C}$ is determined as the safe temperature.

(2) The visibility in a large-space fire field should be no less than $10 \mathrm{~m}$, and the visibility in a small space should be no less than $5 \mathrm{~m}$.

(3) It is generally considered that the tolerance value of the human body is not higher than $500 \mathrm{ppm}$ when the smoke drops to a dangerous height.

2.8. Building Modeling Setting. From the perspective of personnel safety, in the construction fire, the harm of smoke is greater than the casual hazard of the fire. According to statistics, $80 \%$ of the deaths in such fire are caused by smoke. The building modeling process does not consider the damage effect of fire on the internal separation structure of the building but the spread process of the smoke. Set the door connecting the aisle in the room and divide the internal room into a noncombustible wall. Generally, the indoor window is closed. The fire cannot affect the automatic opening of the window, so it is considered to be closed, and at the same time, all the walls are incombustible walls.

\section{Simulation Analysis of Smoke in a Super High-Rise Building}

According to the setting of the fire scenario presented in Table 4, typical scenarios were selected for use in the analysis of the simulation results. The building structure model in the FDS is displayed in Figure 1.

Whether the fire develops in accordance with the heat release rate of the fire depends on the ratio $\left(D^{*} / \delta^{*}\right)$ of the feature size of the fire source to the cell size of the grid where the source is located:

$$
D^{*}=\left(\frac{Q_{\mathrm{f}}}{\rho_{\infty} c_{p} T_{\infty} \sqrt{g}}\right)^{2 / 5}
$$

where $D^{*}$ is the feature size of the fire, $\rho_{\infty}$ is the gas density at ambient temperature in $\mathrm{kg} / \mathrm{m}^{3}, c_{p}$ is specific heat at constant pressure of the gas in $\mathrm{kJ} /(\mathrm{kg} \cdot \mathrm{K}), T_{\infty}$ is ambient temperature in $\mathrm{K}$, and $g$ is gravitational acceleration in $\mathrm{m} / \mathrm{s}^{2}$.

Considering the increase in the heat release rate of the fire source and performance of the computer, the FDS User Manual suggests that the $D^{*} / \delta^{*}$ value is most reasonable within the range of 4 to 16 . Thus, $D^{*} / \delta^{*}$ was calculated according to the cell size of the grid where the fire source was located $\left(\delta^{*}=0.2 \mathrm{~m}\right)$, as detailed in Table 5.

As evident in Table 5, we demonstrated that the grid size was reasonable and that the established fire model was accurate and credible. Furthermore, by employing the adaptive test, we discovered that, to a certain extent, the results did not change significantly (approximately $0.1 \%$ ) when the number of meshes increased, which further illustrated the reliability of the established fire model.

3.1. Fire Conditions of a Single Room in Different States. The thresholds for fire hazard for the three functional rooms are listed in Table 6. The black areas in Figures 2-4 denote the range in which the room reached the critical threshold. The larger the value, the greater the visibility and the lower the risk. Table 6 specifies the critical time required for fire to become a hazard in three scenarios: Catering area $\mathrm{B}>$ shop area $\mathrm{A}>$ office area $\mathrm{C}$.

The analytical results revealed that the critical time required for fire to become a hazard in the shop area did not vary significantly under various failure conditions for the automatic sprinkler system and smoke extraction system. Smoke in all scenarios gathered from the corner. In fire scenarios in which the automatic sprinkler system or smoke extraction system experienced a single failure, critical time required for fire to become a hazard was similar, with a difference $\leq 5 \mathrm{~s}$. The critical time of fire hazard was 
TABLE 4: Fire scenario design for this study.

\begin{tabular}{|c|c|c|c|c|c|}
\hline Fire location & $\begin{array}{c}\text { Fire } \\
\text { scenario }\end{array}$ & $\begin{array}{c}\text { Fire growth } \\
\text { factor }\left(\mathrm{kW} / \mathrm{s}^{2}\right)\end{array}$ & $\begin{array}{l}\text { Sprinkler } \\
\text { system }\end{array}$ & $\begin{array}{c}\text { Smoke } \\
\text { extraction system }\end{array}$ & $\begin{array}{c}\text { Maximum heat } \\
\text { release rate of fire (MW) }\end{array}$ \\
\hline \multirow{4}{*}{ F1 shop A } & A00 & 0.04689 & Invalid & Invalid & 8.0 \\
\hline & A01 & 0.04689 & Invalid & Valid & 8.0 \\
\hline & A10 & 0.04689 & Valid & Invalid & 5.0 \\
\hline & A11 & 0.04689 & Valid & Valid & 5.0 \\
\hline \multirow{4}{*}{ F4 restaurant B } & B00 & 0.04689 & Invalid & Invalid & 8.0 \\
\hline & B01 & 0.04689 & Invalid & Valid & 8.0 \\
\hline & $\mathrm{B} 10$ & 0.04689 & Valid & Invalid & 2.5 \\
\hline & $\mathrm{B} 11$ & 0.04689 & Valid & Valid & 2.5 \\
\hline \multirow{4}{*}{ F15 an office area C } & $\mathrm{COO}$ & 0.04689 & Invalid & Invalid & 6.0 \\
\hline & $\mathrm{C} 01$ & 0.04689 & Invalid & Valid & 6.0 \\
\hline & $\mathrm{C} 10$ & 0.04689 & Valid & Invalid & 1.5 \\
\hline & $\mathrm{C} 11$ & 0.04689 & Valid & Valid & 1.5 \\
\hline \multirow{4}{*}{ F14 an office area and staircase D } & D00 & 0.04689 & Invalid & Invalid & 6.0 \\
\hline & D01 & 0.04689 & Invalid & Valid & 6.0 \\
\hline & D10 & 0.04689 & Valid & Invalid & 1.5 \\
\hline & D11 & 0.04689 & Valid & Valid & 1.5 \\
\hline \multirow{4}{*}{ F14-15 an office area and staircase E } & E00 & 0.04689 & Invalid & Invalid & 6.0 \\
\hline & E01 & 0.04689 & Invalid & Valid & 6.0 \\
\hline & E10 & 0.04689 & Valid & Invalid & 1.5 \\
\hline & E11 & 0.04689 & Valid & Valid & 1.5 \\
\hline \multirow{4}{*}{ F14-15-16 an office area and staircase F } & F00 & 0.04689 & Invalid & Invalid & 6.0 \\
\hline & F01 & 0.04689 & Invalid & Valid & 6.0 \\
\hline & F10 & 0.04689 & Valid & Invalid & 1.5 \\
\hline & F11 & 0.04689 & Valid & Valid & 1.5 \\
\hline
\end{tabular}

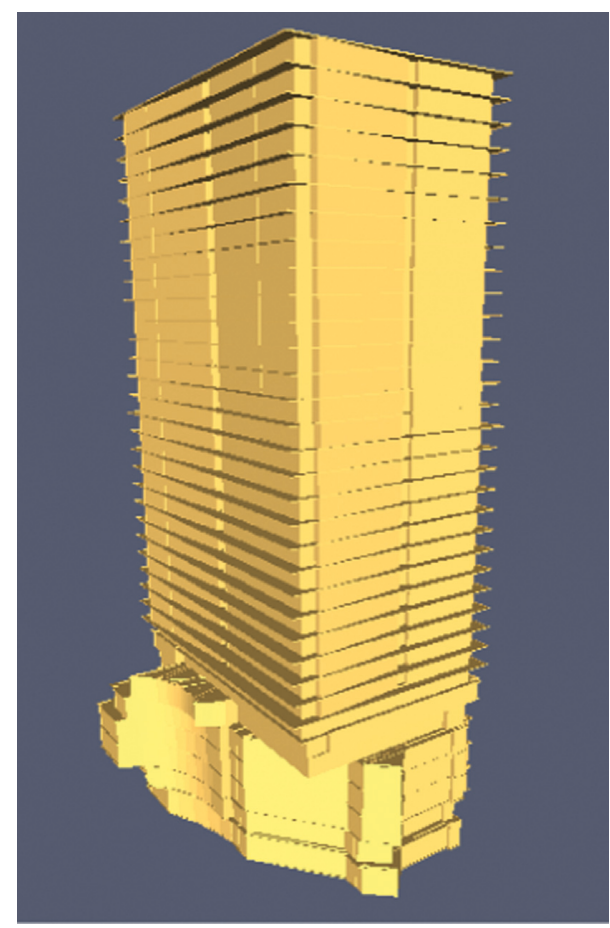

FIGURE 1: The super high-rise building structure model used in FDS.

approximately $200 \mathrm{~s}$ in all the aforementioned fire scenarios, but the maximum straight-line distance from any point in the room to the evacuation gate was $20 \mathrm{~m}$ for high-rise buildings with first-rate and second-rate fire-resistance.
Table 5: $Q$ vs. $D^{*}$ and $D^{*} / \delta^{*}$ values.

\begin{tabular}{lccccc}
\hline$Q(\mathrm{~kW})$ & 8 & 6 & 5 & 2.5 & 1.5 \\
\hline$D^{*}$ & 2.18 & 1.95 & 1.81 & 1.37 & 1.12 \\
$D^{*} / \delta^{*}$ & 10.90 & 9.75 & 9.05 & 6.85 & 5.60 \\
\hline
\end{tabular}

TABle 6: Critical time required for fire to become a hazard for the three functional rooms.

\begin{tabular}{lcc}
\hline Fire location & Fire scenario & $\begin{array}{c}\text { Critical time required for } \\
\text { fire to become a hazard (s) }\end{array}$ \\
\hline \multirow{4}{*}{ F1 shop area A } & A00 & 184 \\
& A01 & 196 \\
& A10 & 191 \\
& A11 & 212 \\
\hline \multirow{3}{*}{ F4 catering area B } & B00 & 190 \\
& B01 & 196 \\
& B10 & 194 \\
F15 an office area C & B11 & 214 \\
& C00 & 119 \\
& C10 & 121 \\
& C11 & 124 \\
\end{tabular}

Therefore, this length of time is sufficient to ensure that people can escape from a single room.

3.2. Fire Conditions of Different Functional Places in the Same State. Scenarios A10, B10, and C10 were selected for 


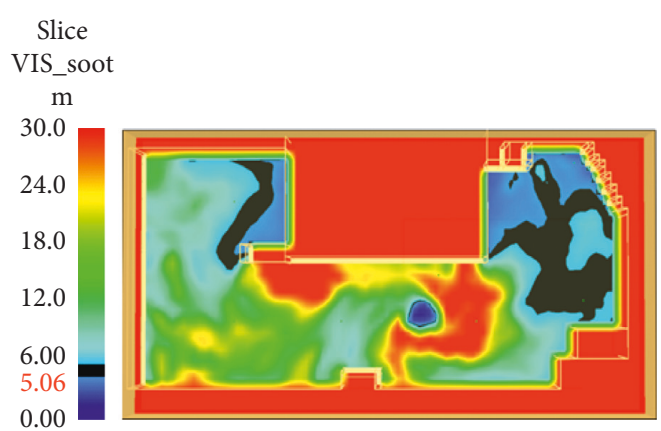

(a)

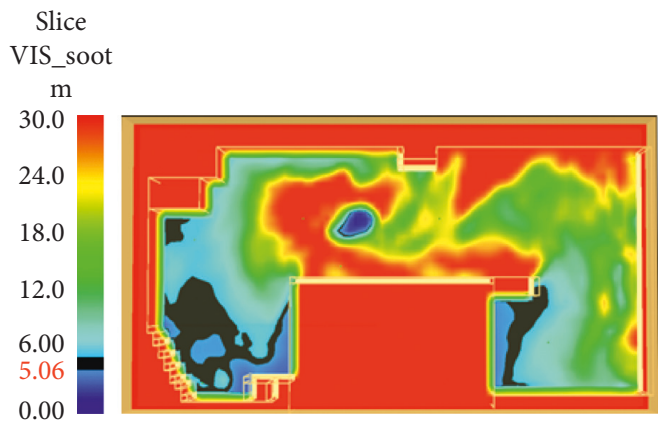

(c)

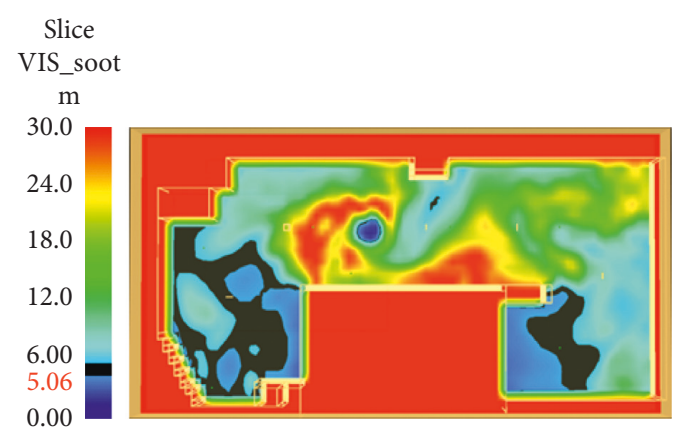

(b)

Slice

VIS_soot

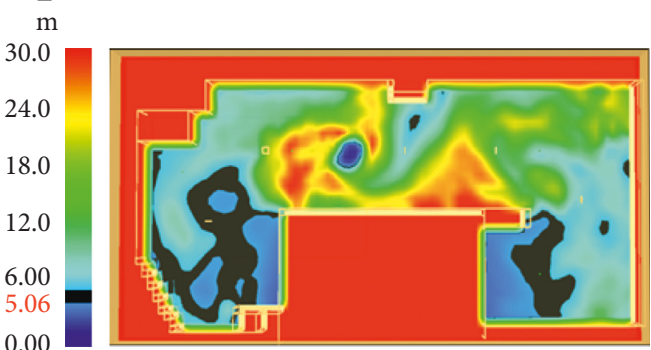

(d)

Figure 2: Critical time of fire hazard for scenario A. (a) A00, (b) A01, (c) A10, and (d) A11.

comparative analysis in which the fire type was a fire controlled by a sprinkler system.

As can be clearly seen from Figures 5 and 6 , the CO mass fraction did not reach the critical value at $600 \mathrm{~s}$, and the entire space of the three different functional sites all reached a dangerous temperature. Therefore, the criterion of $\mathrm{CO}$ mass fraction did not play a role in the parameters affecting evacuation time and reduced the critical time required for temperature to become a hazard. At $1800 \mathrm{~s}$, the temperature at the fire source decreased and the fire became smaller, which was related to the fact that the fire scenario selected featured a dysfunctional smoke extraction system and an effective sprinkler system. The temperature and CO mass fraction growth in scenario C10 were faster than those of scenarios A10 and B10. Thus, fire prevention in the office area should be taken seriously because the office areas comprised the majority of super high-rise buildings.

3.3. Fire Spread. As the fire occurred in a room in the building, smoke, heat radiation, and temperature promptly augmented the space, and the smoke spread along various gaps to other areas. During the process of evacuating personnel to the staircase, the accommodation space in the front chamber was limited. Therefore, staff would require a certain space in the aisle.

Scenario D10 was selected for simulation and analysis of the situation in which the automatic sprinkler system was effective but the smoke extraction system was faulty. In the simulation, changes in fire temperature were evaluated by setting thermocouple points, as displayed in Figure 7.
The thermocouples were arranged in the key area of the F14 room, and its connected staircase at a height of $2 \mathrm{~m}$ from the roof to detect temperature changes, as displayed in Figure 8.

F14-1 and F14-3 were the thermocouples in the front chamber of the staircase, and F14-2 and F14-4 were the thermocouples in the staircase. F14-aisle 1, F14-aisle 2, F14aisle 3, and F14-aisle 4 were the thermocouples in the aisle, and F14-aisle 1 was located $5 \mathrm{~m}$ beneath the fire point. The distance between two adjacent thermocouples was $5 \mathrm{~m}$, and because the area was relatively symmetrical, thermocouples were arranged on the left side only. F14-door 1 and F14-door 2 were thermocouples at the door of the room, and the distance from the fire source was 17 and $4 \mathrm{~m}$, respectively. F14-room 1, F14-room 2, and F14-room 3 were thermocouples in the room with distances from the red fire source of 5,10 , and $15 \mathrm{~m}$, respectively.

According to the simulation results, as displayed in Figure 9 , the CO mass fraction at $1800 \mathrm{~s}$ was at most $3 \times 10^{-4}$, which did not exceed the maximum tolerance limit of $5 \times 10^{-4}$. Therefore, CO does not generally affect the safety evacuation.

In practice, visibility is a parameter closely related to smoke, as indicated in Figure 10, where black is the critical line of visibility for people, with a value of $5 \mathrm{~m}$. The rate of smoke spreading and lowering was exceptionally high, with an adjacent open area being affected almost every $60 \mathrm{~s}$. At $101 \mathrm{~s}$, the top of the room began to gather smoke. At $162 \mathrm{~s}$, the smoke had filled the entire room and spread to the top of the outside aisle, whereas visibility in the room exceeded the visual distance of a person. At $221 \mathrm{~s}$, smoke 


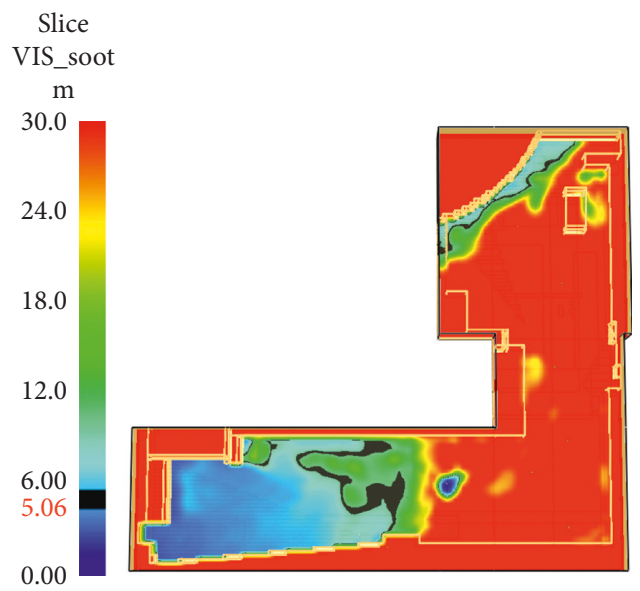

(a)

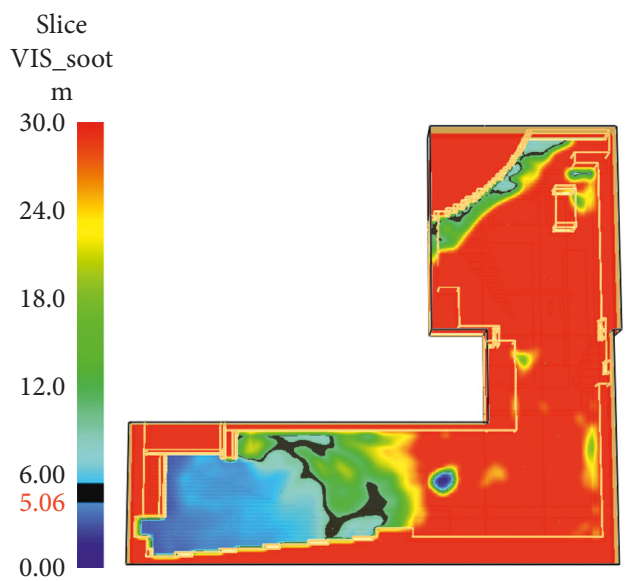

(c)

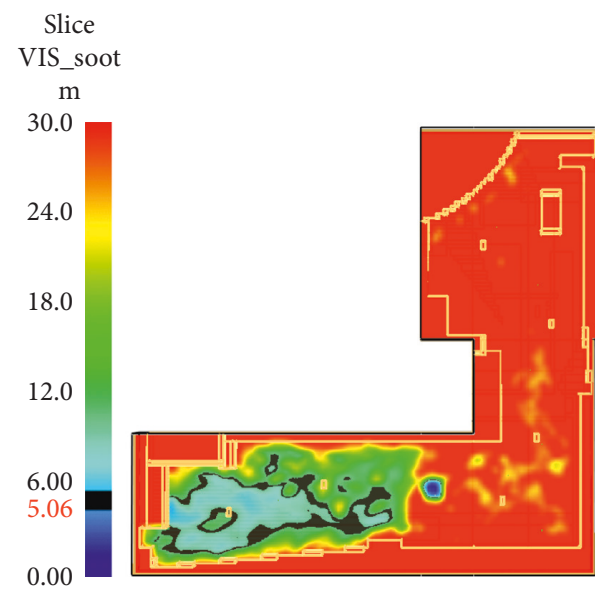

(b)

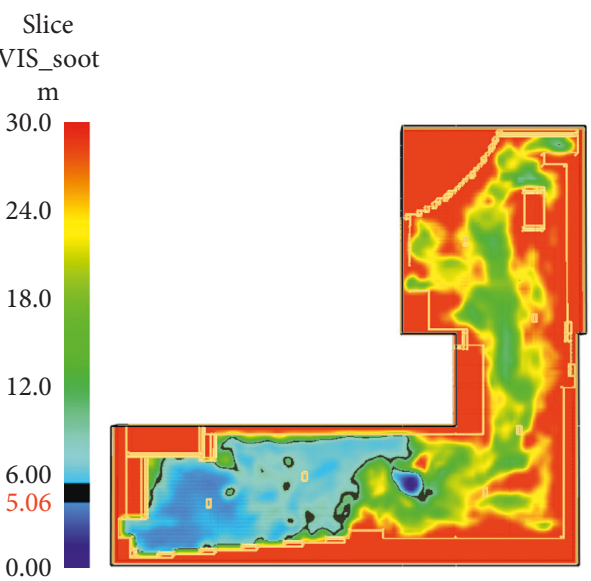

(d)

Figure 3: Critical time of fire hazard for scenario B. (a) B00, (b) B01, (c) B10, and (d) B11.

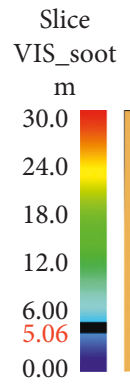

Slice

VIS_soot

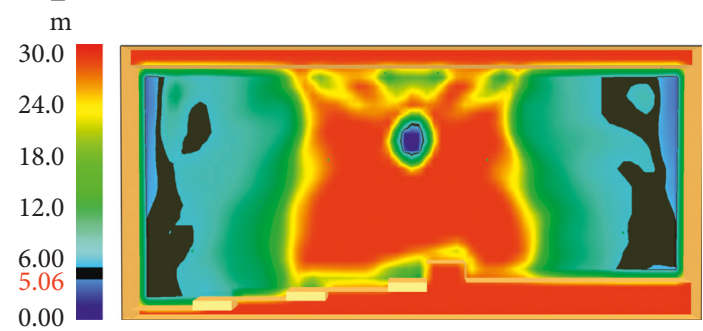

(c)

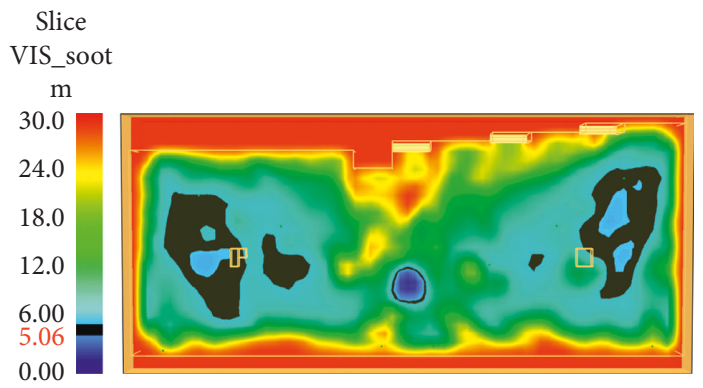

(b)

$$
\text { Slice }
$$

VIS_soot

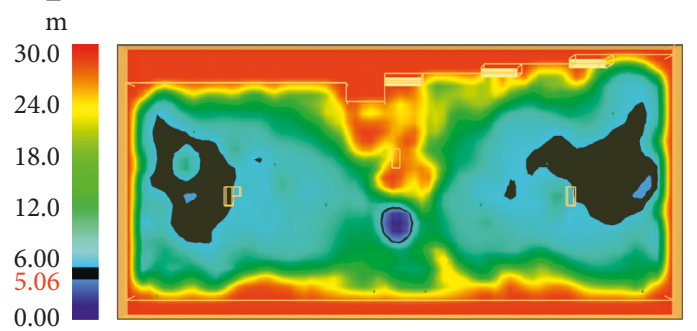

(d)

Figure 4: Critical time of fire hazard for scenario C. (a) C00, (b) C01, (c) C10, and (d) C11. 


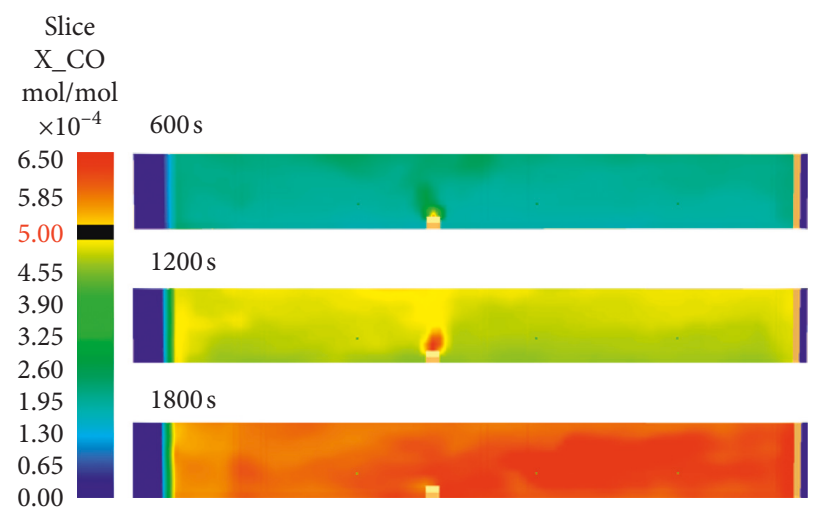

(a)

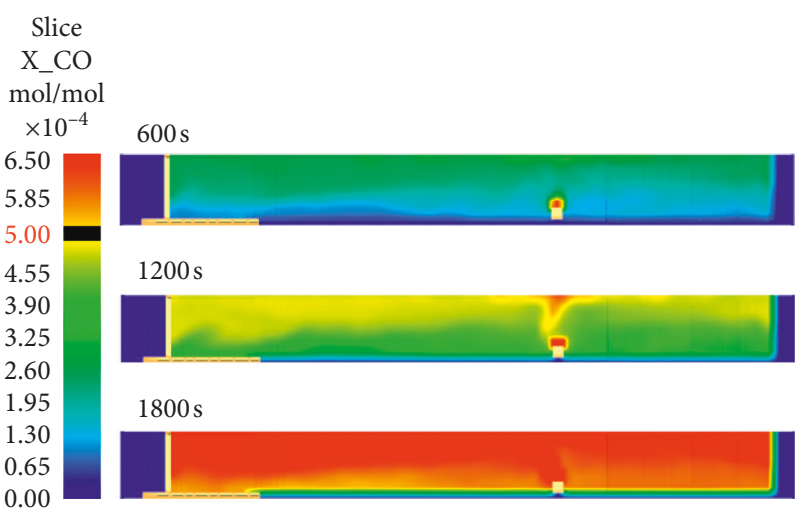

(b)

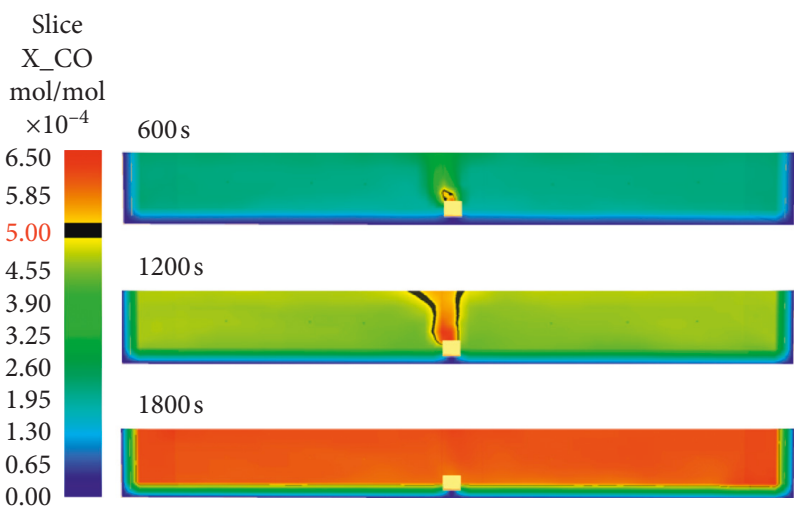

(c)

Figure 5: Slices of the CO mass fraction in different scenarios. (a) A10, (b) B10, and (c) C10.

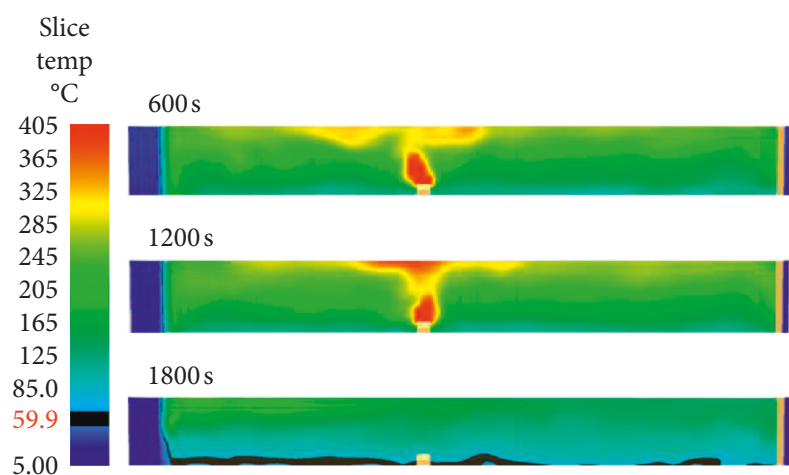

(a)

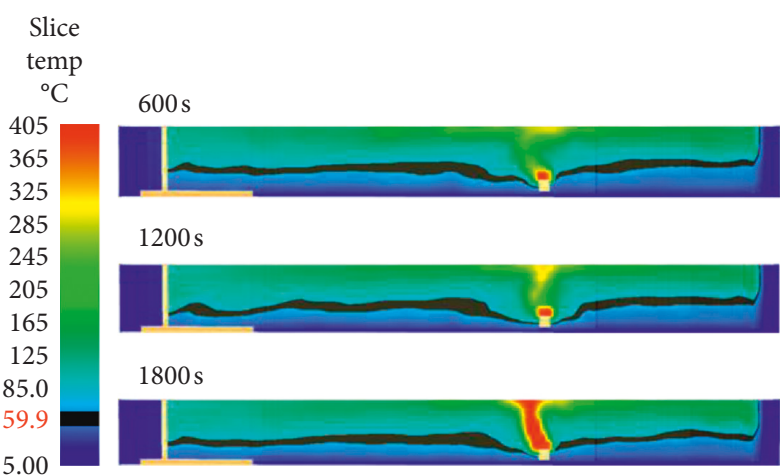

(b)

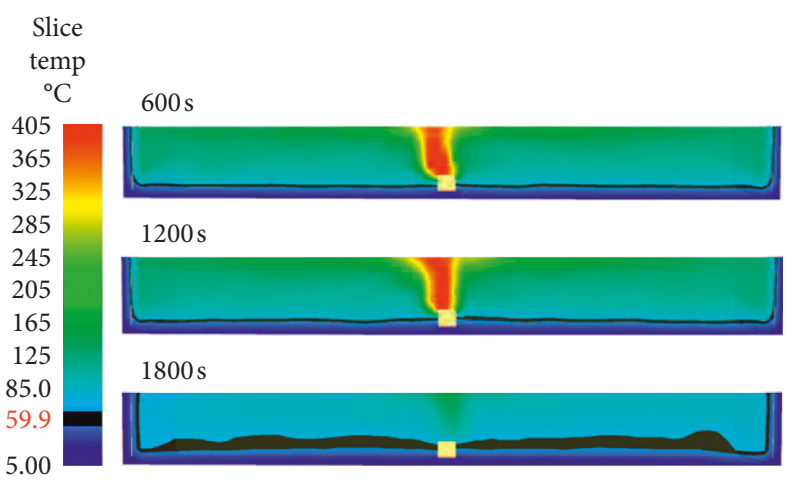

(c)

FIgURE 6: Slices of the temperature in different scenarios. (a) A10, (b) B10, and (c) C10. 


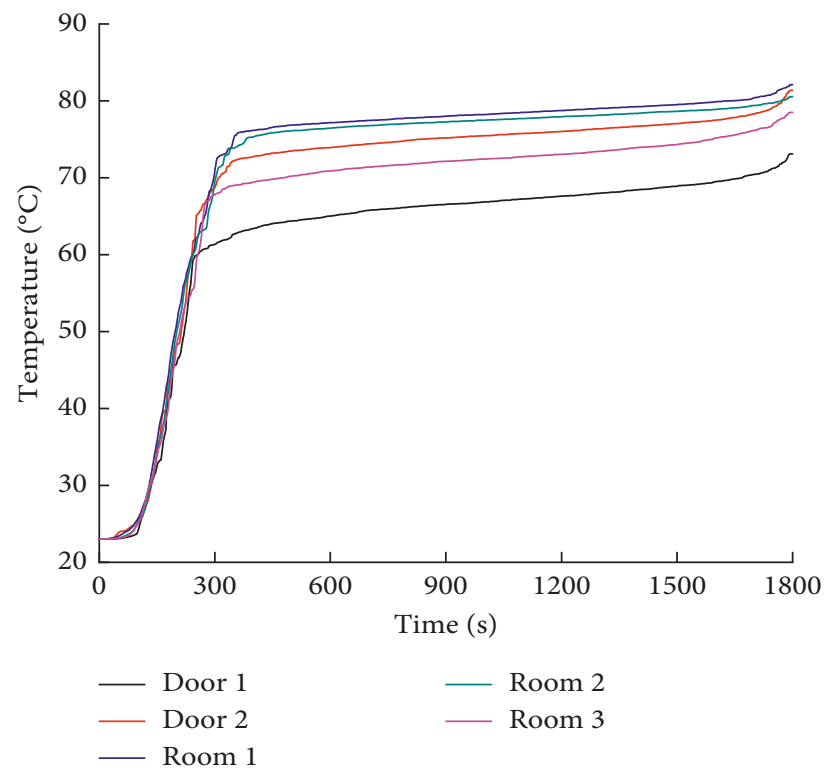

Figure 7: Temperature vs. time inside the room in fire scenario D10.

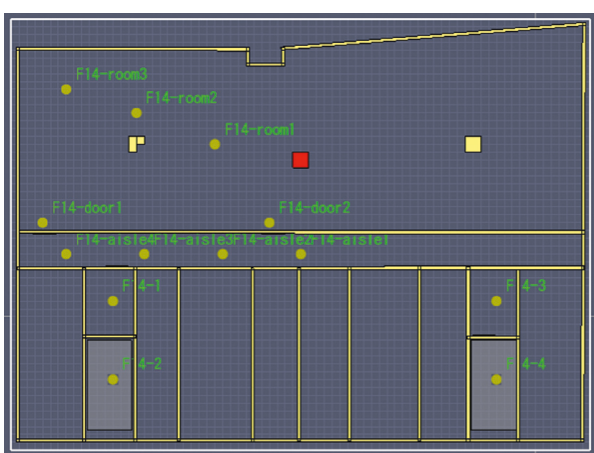

(a)

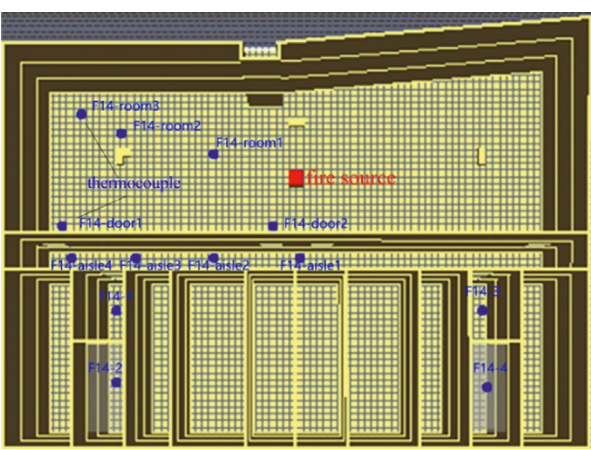

(b)

FIGURE 8: Thermocouple arrangements of F14. (a) 2D thermocouple arrangements; (b) 3D thermocouple arrangements.

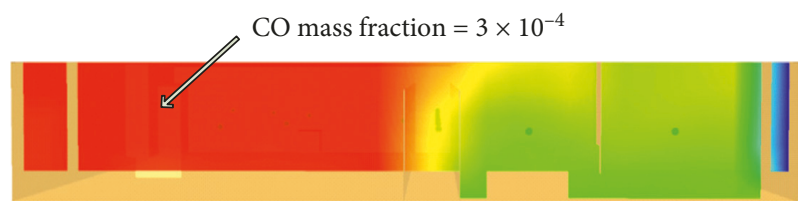

FIgURE 9: Slice of the CO mass fraction at $1800 \mathrm{s.}$

continued to sink lower in the aisle, spread to the front of the stairs, and then began to gather at the top of the front chamber. At $292 \mathrm{~s}$, the smoke spread to the staircase and gathered at the top of the staircase, further threatening safety evacuation of personnel. At $508 \mathrm{~s}$, the smoke filled the entire space, and all areas were invisible, which seriously affected the normal actions of the personnel.

According to the temperature detected by thermocouples, as presented in Figure 11, the temperature inside the room was higher than $60^{\circ} \mathrm{C}$, which exceeded the temperature range bearable to the human body. In the room, the temperature was higher at greater distances from the fire source; after $200 \mathrm{~s}$, the temperature detection point tended to remain stable, with $T_{\text {room } 1}>T_{\text {room2 }}>T_{\text {room3 }}$, $T_{\text {door2 }}>T_{\text {door } 1}>60^{\circ} \mathrm{C} . T_{\text {door1 }}$ had the lowest average temperature, which remained stable at $65^{\circ} \mathrm{C}$ after $200 \mathrm{~s}$. The distance between door 2 and the fire source was $4 \mathrm{~m}$, but heat was exchanged inside and outside the room and reduced the temperature of door 2 because the door was open and the temperature outside the room was lower than the temperature inside the room. Accordingly, $T_{\text {room } 2}>T_{\text {door2 }}$, as presented in Figure 7.

Compared with the temperature inside the room, the temperature outside the room (Figure 12) was generally much lower. The maximum temperature did not exceed $52^{\circ} \mathrm{C}$, which was lower than the $60^{\circ} \mathrm{C}$ threshold for tolerability by the human body. After $200 \mathrm{~s}$, the temperature remained steady, with $T_{\text {aisle }}>T_{\text {stairroom }}>T_{\text {fore-room }}>28^{\circ} \mathrm{C}$ and $T_{\text {aisle4 }}>T_{\text {aisle3 }}>T_{\text {aisle2 }}>T_{\text {aislel }}>42^{\circ} \mathrm{C}$.

A comparison of the three fire criteria ( $\mathrm{CO}$ mass fraction, visibility, and temperature) revealed that the dominant factor with the most significant effect on safety 


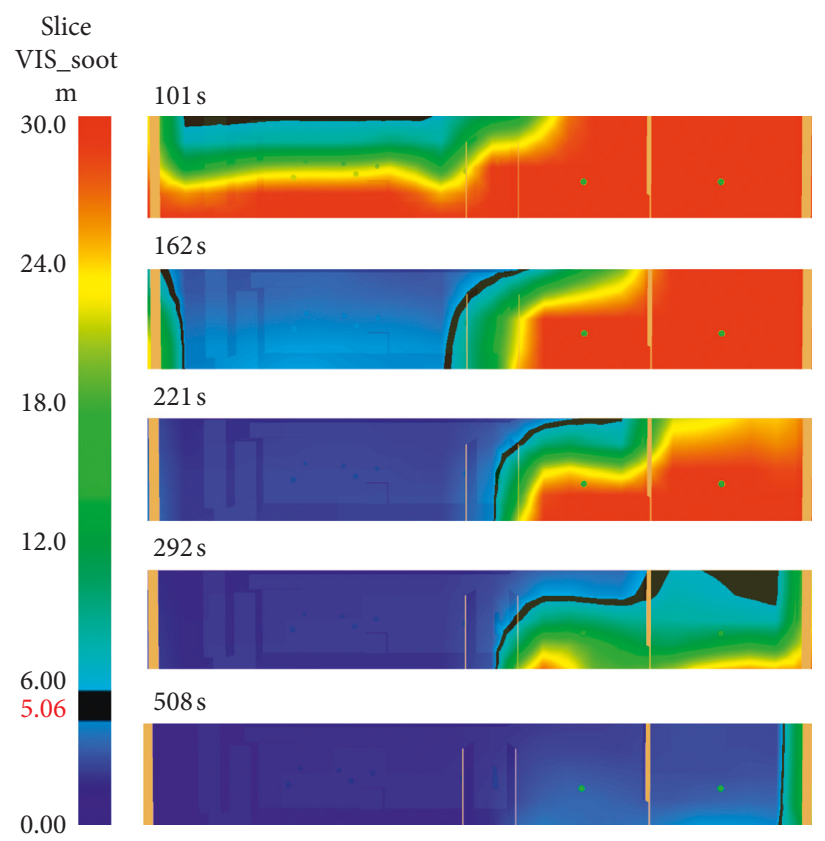

FIgURE 10: Visibility slice of fire scenario D10.

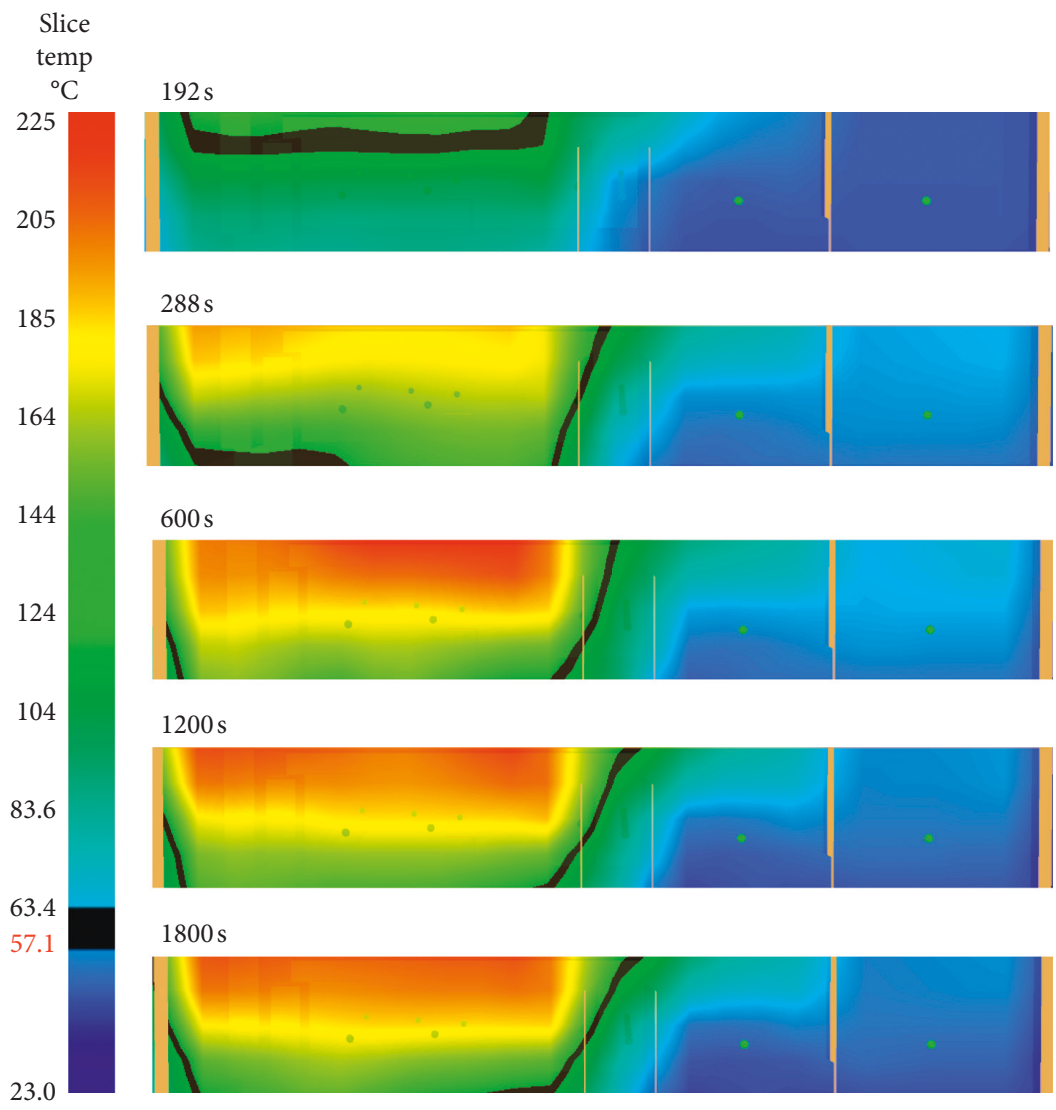

Figure 11: Temperature slice of fire scenario D10.

evacuation time was visibility. Relevant studies have demonstrated that smoke is the primary cause of death during fires [36-38]. Therefore, the first step during evacuation is to leave the fire room quickly and avoid remaining in a corner, which can effectively prevent harm caused by smoke. 


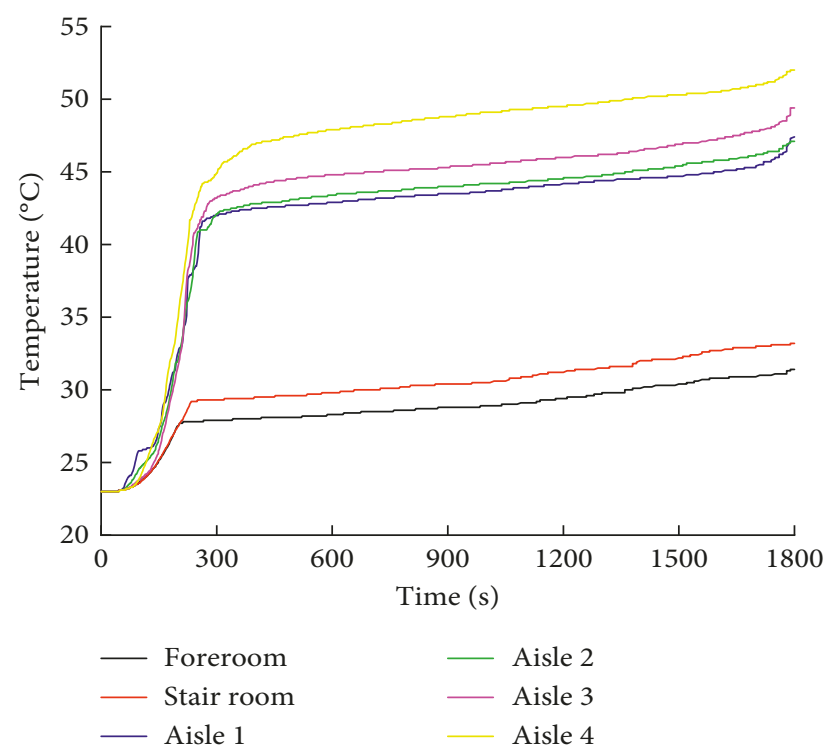

Figure 12: Temperature vs. time outside the room of fire scenario D10.

Fire scenario E is displayed in Figure 13; the grid is the fire simulation area in which the temperature condition of the upper floor was the same as that of the lower floor when the fire occurred. The thermocouple arrangement in F14 was the same as in fire scenario D, and the measuring points were arranged in the walkway on the 15 th floor, the staircase, and its front chamber, the same as in F14.

Fire scenario $\mathrm{F}$ is displayed in Figure 14, and the thermocouple arrangement in F14 was the same as scenario D. The thermocouples of F15 and F16 were arranged in the walkway in the same manner as in F14, as were the staircase and its front chamber.

According to the simulation results of fire scenarios $\mathrm{E}$ and $\mathrm{F}$ detected by the thermocouples, the temperature of the staircase and its front chamber in the two scenarios were always lower than the threshold temperature of $60^{\circ} \mathrm{C}$ for tolerance by the human body. From the perspective of temperature, when a fire occurred in scenarios $\mathrm{E}$ and $\mathrm{F}$, the staircase and its front chamber were relatively safer areas that could be used to temporarily protect personnel.

\section{Conclusions}

To acquire a comprehensive understanding of the laws of fire spread in super high-rise buildings, a FDS simulation was performed on the Saigao office in Shaanxi Province, China. The conclusions of the simulation are as follows:

(1) The critical time required for the same type of fire to become a hazard in a shop, a restaurant, or an office was slightly more than $200 \mathrm{~s}$, with the critical time being shortest in the office area, indicating that protecting and monitoring the office area for fire safety should be a priority.

(2) Compared with temperature and CO mass fraction, visibility was closely related to smoke because it had

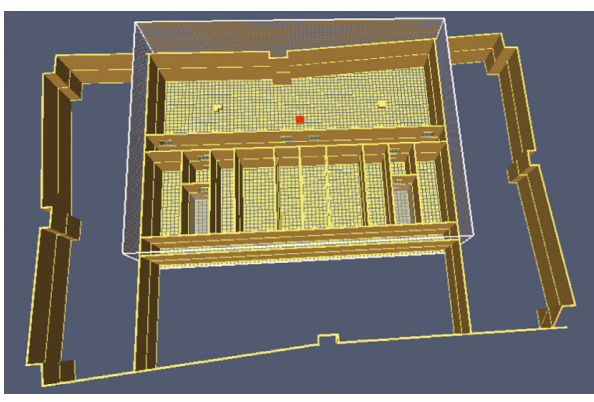

FIGURE 13: Structure of fire scenario E.

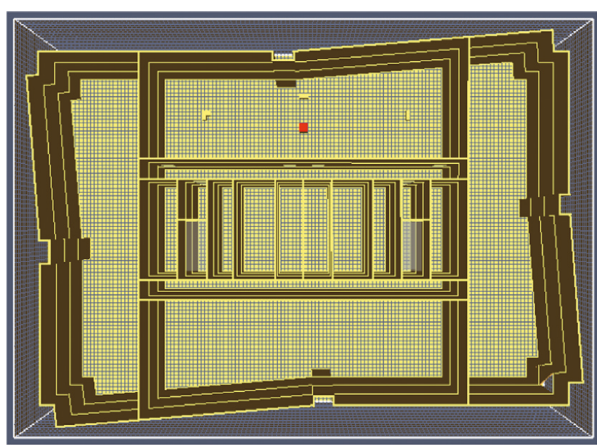

FIGURE 14: Structure of fire scenario F.

the most significant effect on the critical time required for fire to become a hazard. The critical time required for fire to become a hazard determined in terms of visibility was significantly shorter than temperature or $\mathrm{CO}$ mass fraction.

(3) The speed at which smoke spread and lowered was extremely fast, and smoke always began to accumulate and spread from the corner and the ceiling. From the perspective of visibility, smoke would affect an adjacent open area in almost every $60 \mathrm{~s}$.

\section{Data Availability}

The data used to support the findings of this study are available from the corresponding author upon request.

\section{Conflicts of Interest}

The authors declare that they have no conflicts of interest.

\section{Authors' Contributions}

Xin Yi and Changkui Lei equally contributed to this work.

\section{Acknowledgments}

This work was supported by the National Nature Science Foundation Funded Project of China (grant no. 5180-4247). The authors are grateful to the guidance of various experts during paper writing and numerical simulations. 


\section{References}

[1] Z. Lu, X. He, and Y. Zhou, "Performance-based seismic analysis on a super high-rise building with improved viscously damped outrigger system," Structural Control and Health Monitoring, vol. 25, no. 8, article e2190, 2018.

[2] J. Ma, W. G. Song, W. Tian, S. M. Lo, and G. X. Liao, "Experimental study on an ultra high-rise building evacuation in China," Safety Science, vol. 50, no. 8, pp. 1665-1674, 2012.

[3] V. J. L. Gan, M. Deng, K. T. Tse, C. M. Chan, I. M. C. Lo, and J. C. P. Cheng, "Holistic BIM framework for sustainable low carbon design of high-rise buildings," Journal of Cleaner Production, vol. 195, pp. 1091-1104, 2018.

[4] J. Li, B. Rismanchi, and T. Ngo, "Feasibility study to estimate the environmental benefits of utilising timber to construct high-rise buildings in Australia," Building and Environment, vol. 147, pp. 108-120, 2019.

[5] R. Gao, Z. Fang, A. Li, C. Shi, and L. Che, "Estimation of building ventilation on the heat release rate of fire in a room," Applied Thermal Engineering, vol. 121, pp. 1111-1116, 2017.

[6] C.-Y. Cho, Y. Lee, M.-Y. Cho, S. Kwon, Y. Shin, and J. Lee, "An optimal algorithm of the multi-lifting operating simulation for super-tall building construction," Automation in Construction, vol. 35, pp. 595-607, 2013.

[7] L. Wang, X.-Y. Fan, S.-G. Liang, J. Song, and Z.-K. Wang, "Improved expression for across-wind aerodynamic damping ratios of super high-rise buildings," Journal of Wind Engineering and Industrial Aerodynamics, vol. 176, pp. 263-272, 2018.

[8] P. S. Nimlyat, A. U. Audu, E. O. Ola-Adisa, and D. Gwatau, "An evaluation of fire safety measures in high-rise buildings in Nigeria," Sustainable Cities and Society, vol. 35, pp. 774-785, 2017.

[9] M. Li, Z. Gao, J. Ji, and K. Li, "Modeling of positive pressure ventilation to prevent smoke spreading in sprinklered highrise buildings," Fire Safety Journal, vol. 95, pp. 87-100, 2018.

[10] L. Hu, J. A. Milke, and B. Merci, "Special issue on fire safety of high-rise buildings," Fire Technology, vol. 53, no. 1, pp. 1-3, 2017.

[11] T. T. Lie and J. H. Mcguire, "Control of smoke in high-rise buildings,” Fire Technology, vol. 11, no. 1, pp. 5-14, 1975.

[12] G. Hadjisophocleous and Q. Jia, "Comparison of FDS prediction of smoke movement in a 10-storey building with experimental data," Fire Technology, vol. 45, no. 2, pp. 163-177, 2009.

[13] Y. Wang, E. Zalok, and G. Hadjisophocleous, "An experimental study of smoke movement in multi-storey buildings," Fire Technology, vol. 47, no. 4, pp. 1141-1169, 2011.

[14] A. Cowlard, A. Bittern, C. Abecassis-Empis, and J. Torero, "Fire safety design for tall buildings," Procedia Engineering, vol. 62, pp. 169-181, 2013.

[15] A. Soltanzadeh, M. Alaghmandan, and H. Soltanzadeh, "Performance evaluation of refuge floors in combination with egress components in high-rise buildings," Journal of Building Engineering, vol. 19, pp. 519-529, 2018.

[16] J. Zhu, R. Huo, and Y. Fu, "Smoke control in super tall buildings," Fire Science and Technology, vol. 26, no. 1, pp. 54-57, 2007.

[17] L.-F Hou, M. Li, W.-Y Cui, and Y.-C Liu, "Numerical simulation and analysis of on-building high-rise building fires," Procedia Engineering, vol. 11, pp. 127-134, 2011.

[18] X. Liu, H. Zhang, and Q. Zhu, "Factor analysis of high-rise building fires reasons and fire protection measures," Procedia Engineering, vol. 45, pp. 643-648, 2012.

[19] J. Yang, Y. Yang, and Y. Chen, "Numerical simulation of smoke movement influence to evacuation in a high-rise residential building fire," Procedia Engineering, vol. 45, pp. 727-734, 2012.

[20] Y. Xia, "Simulation on spread of fire smoke in the elevator shaft for a high-rise building," Theoretical and Applied Mechanics Letters, vol. 4, no. 3, article 034007, 2014.

[21] H. Cheng and G. V. Hadjisophocleous, "Dynamic modeling of fire spread in building," Fire Safety Journal, vol. 46, no. 4, pp. 211-224, 2011.

[22] J. Jiang, L. Chen, S. Jiang, G.-Q. Li, and A. Usmani, "Fire safety assessment of super tall buildings: a case study on Shanghai Tower," Case Studies in Fire Safety, vol. 4, pp. 28-38, 2015.

[23] J. Sun, L. Hu, and Y. Zhang, "A review on research of fire dynamics in high-rise buildings," Theoretical and Applied Mechanics Letters, vol. 3, no. 4, article 042001, 2013.

[24] J. Zhang and C. Ren, "Discussion on fire safety design of super high-rise building," Fire Science and Technology, vol. 31, no. 9, pp. 941-943, 2012.

[25] J. Chen, J. Ma, and S. M. Lo, "Event-driven modeling of elevator assisted evacuation in ultra high-rise buildings," Simulation Modelling Practice and Theory, vol. 74, pp. 99-116, 2017.

[26] E. Yu-ting and L. Zhou, "The research on the current safety status of high-rise building at home and abroad," Procedia Engineering, vol. 135, pp. 574-577, 2016.

[27] X.-Y. Xu, Z.-H. Wang, X.-Y. Liu et al., "Study on fire smoke control in super-high building atrium," Procedia Engineering, vol. 211, pp. 844-852, 2018.

[28] P. Panindre, N. S. S. Mousavi, and S. Kumar, "Positive pressure ventilation for fighting wind-driven high-rise fires: simulation-based analysis and optimization," Fire Safety Journal, vol. 87, pp. 57-64, 2017.

[29] X. Zhang, "Study on rapid evacuation in high-rise buildings," Engineering Science and Technology, an International Journal, vol. 20, no. 3, pp. 1203-1210, 2017.

[30] D. Qi, L. Wang, J. Ji, and M. Li, "Dimensionless analytical solutions for steady-state fire smoke spread through high-rise shaft," Fire Safety Journal, vol. 93, pp. 12-20, 2017.

[31] Y. Ding, L. Yang, F. Weng, Z. Fu, and P. Rao, "Investigation of combined stairs elevators evacuation strategies for high rise buildings based on simulation," Simulation Modelling Practice and Theory, vol. 53, pp. 60-73, 2015.

[32] G.-Y. Wu and H.-C. Huang, "Modeling the emergency evacuation of the high rise building based on the control volume model," Safety Science, vol. 73, pp. 62-72, 2015.

[33] G. Zhao, T. Beji, and B. Merci, "Study of FDS simulations of buoyant fire-induced smoke movement in a high-rise building stairwell," Fire Safety Journal, vol. 91, pp. 276-283, 2017.

[34] NFPA130, Standard for Fixed Guide way Transit and Passenger Rail Systems Quincy, National Fire Protection Association, Quincy, MA, USA, 2000.

[35] Shanghai Fire Research Institute of the Ministry of Public Security and Shanghai Fire Bureau, Technical Specification for Building Smoke Control DGJ08-88-2006, Shanghai Construction and Transportation Committee, Shanghai, China, 2006.

[36] F. Mei, F. Tang, X. Ling, and J. Yu, "Evolution characteristics of fire smoke layer thickness in a mechanical ventilation tunnel with multiple point extraction," Applied Thermal Engineering, vol. 111, pp. 248-256, 2017.

[37] M. Zhong, C. Shi, L. He, J. Shi, C. Liu, and X. Tian, "Smoke development in full-scale sloped long and large curved tunnel fires under natural ventilation," Applied Thermal Engineering, vol. 108, pp. 857-865, 2016.

[38] Y. Alarie, "Toxicity of fire smoke," Critical Reviews in Toxicology, vol. 32, no. 4, pp. 259-289, 2002. 


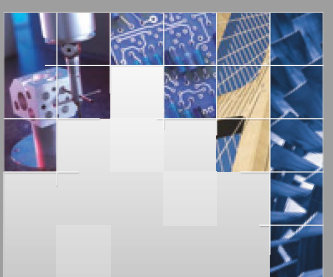

\section{Enfincering}
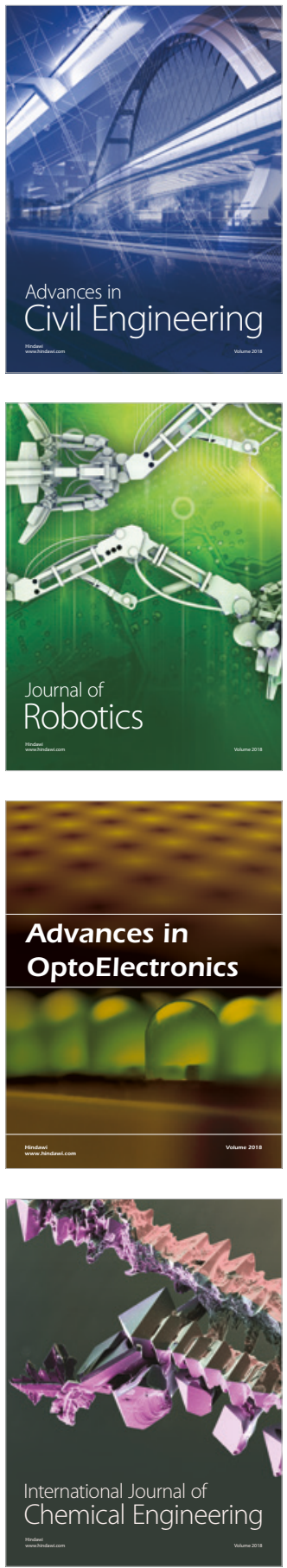

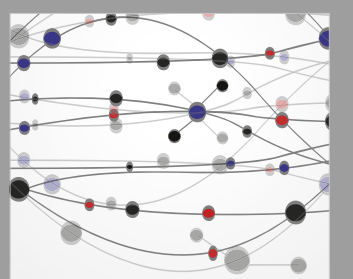

\section{Rotating \\ Machinery}

The Scientific World Journal

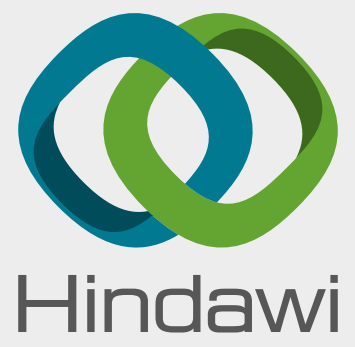

Submit your manuscripts at

www.hindawi.com
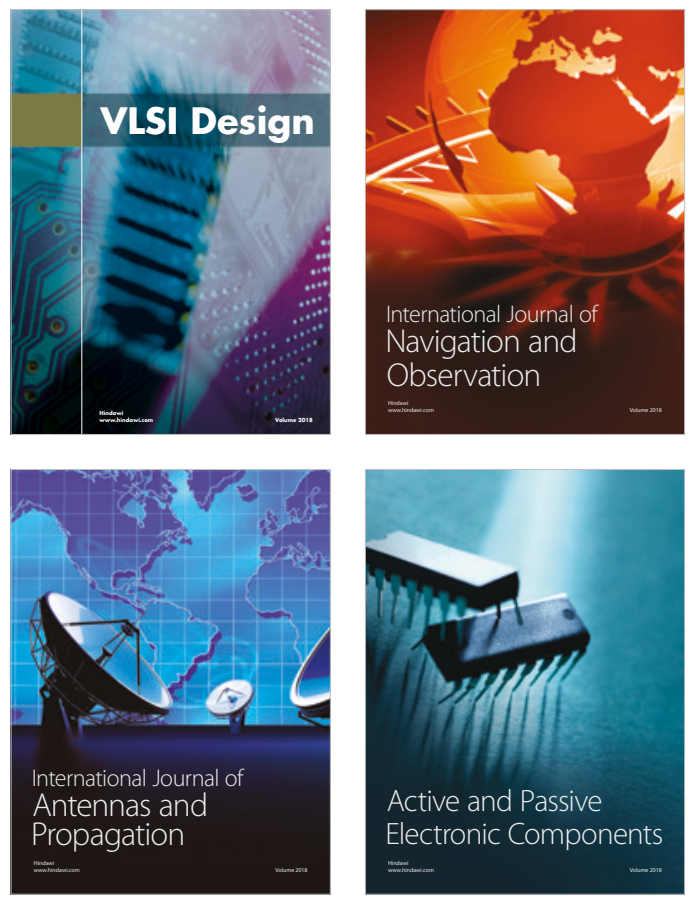
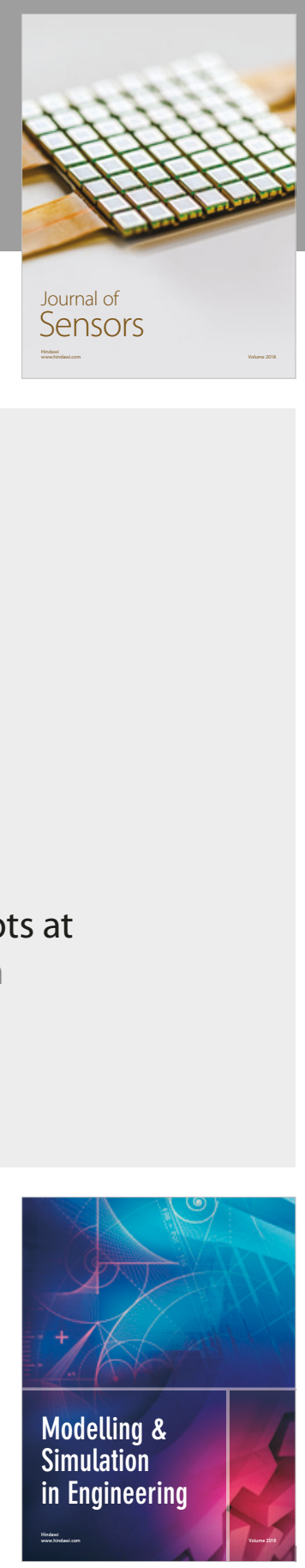

\section{Advances \\ Multimedia}
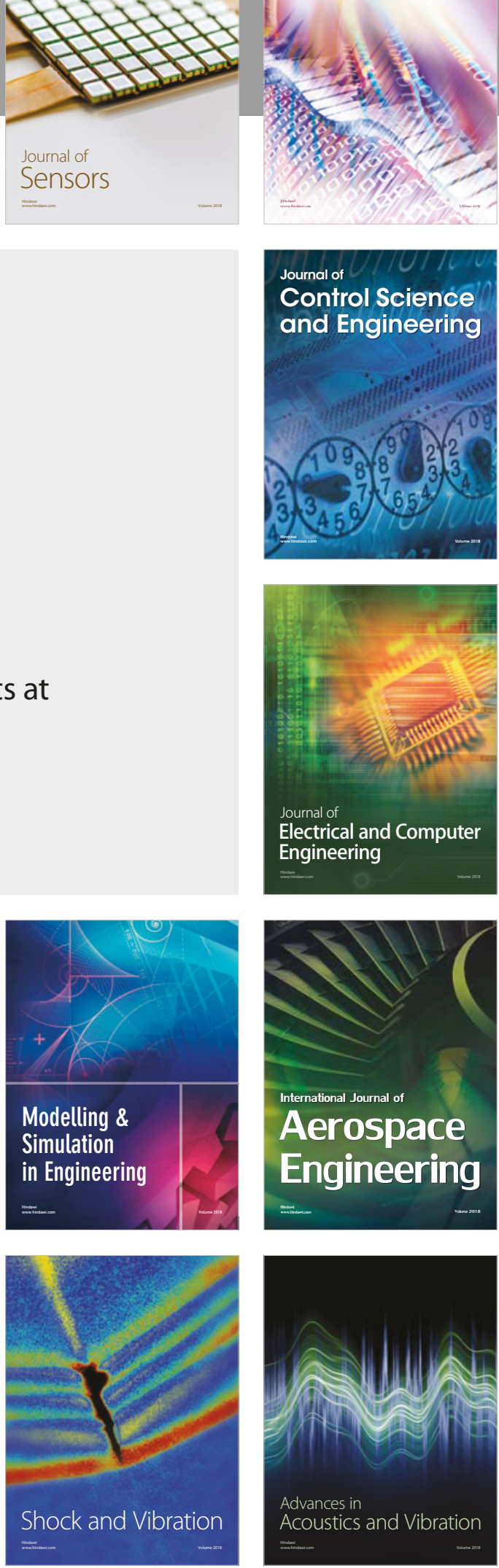